\title{
Peningkatan Kecerdasan Interpersonal melalui Kegiatan Menggambar pada Anak Usia Dini
}

\author{
Yolanda Pahrul $^{1 凶}$, Sofia Hartati ${ }^{2}$, Sri Martini Meilani ${ }^{3}$ \\ Pendidikan Anak Usia Dini, Universitas Negeri Jakarta
}

\begin{abstract}
Abstrak
Penelitian ini bertujuan untuk mendeskripsikan proses dan hasil belajar melalui kegiatan menggambar dalam meningkatkan kecerdasan interpersonal. Penelitian ini dilakukan di TK Islam Nusantara, Kota Serang pada bulan Maret 2018. Subjek penelitian adalah kelompok B sebanyak 14 siswa. Penelitian ini menggunakan metode penelitian tindakan. Prosedur penelitian terdiri dari: perencanaan, tindakan dan observasi, refleksi. Dilakukan untuk 16 pertemuan dibagi menjadi dua siklus. Teknik pengumpulan data dilakukan melalui tes, observasi, wawancara dan studi dokumentasi. Teknik analisis data yang digunakan dalam penelitian ini adalah analisis data kualitatif dan kuantitatif. Pra tindakan dilakukan untuk menentukan persentase kecerdasan interpersonal sebesar 50,89\%, meningkat menjadi 64,55\% setelah siklus pertama, dan meningkat menjadi $85 \%$ setelah siklus kedua. Peningkatan $85 \%$ pada siklus kedua membuktikan bahwa kegiatan menggambar dapat meningkatkan kecerdasan interpersonal anak usia dini. Kecerdasan interpersonal dapat dikembangkan melalui kegiatan menggambar, di mana melalui menggambar anak-anak dapat berinteraksi selain mengekspresikan emosi. Menggambar adalah kegiatan yang sangat menyenangkan bagi anak-anak.
\end{abstract}

Keywords : kecerdasan interpersonal; kegiatan menggambar; penelitian tindakan

\begin{abstract}
This study aims to describe the process and learning outcomes through drawing activities in improving interpersonal intelligence. This research was conducted at TK Islam Nusantara, Serang City in March 2018. The subjects of the study were B group of 14 students. This research uses action research method. The research procedure consists of: planning, action and observation, reflection. Conducted for 16 meetings divided into two cycles. Data collection techniques are conducted through tests, observations, interviews and documentation studies. Data analysis technique used in this research is qualitative and quantitative data analysis. Pre-action was performed to determine the percentage of interpersonal intelligence of $50.89 \%$, increased to $64.55 \%$ after the first cycle, and increased to $85 \%$ after the second cycle. The $85 \%$ increase in the second cycle proves that drawing activities can improve the interpersonal intelligence of early childhood. Interpersonal intelligence can be developed through drawing activities, where through drawing children can interact in addition to expressing emotions. Drawing is a very fun activity for children.
\end{abstract}

Keywords : interpersonal intelligence; drawing activities; action research

Copyright (c) 2019 Yolanda Pahrul, Sofia Hartati, Sri Martini Meilani

$\triangle$ Corresponding author :

Address : Padang, Sumatera Barat, Indonesia

Email : yolandapahrul@gmail.com

ISSN 2356-1327 (Media Cetak)

ISSN 2549-8959 (Media Online) 
462 Peningkatan Kecerdasan Interpersonal melalui Kegiatan Menggambar

\section{PENDAHULUAN}

Anak usia dini adalah individu yang terus mengalami pertumbuhan dan perkembangan. Pada masa ini perkembangan otak sangatlah pesat sehingga masa ini disebut juga dengan "golden age". Tahun-tahun awal kehidupan atau masa emas ini adalah kesempatan untuk membangun pondasi yang baik dan kuat. Banyak penelitian yang menyatakan bahwa pengalaman pertama, dapat mempengaruhi aspek-aspek perkembangan. Apabila pengalaman yang dialami anak adalah pengalaman yang positif, maka akan berpengaruh baik juga pada aspek perkembangan. Begitu juga sebaliknya, jika pengalaman yang dialami adalah negatif, maka akan berdampak buruk pada anak terutama pada kesehatan mental, perilaku dan sosial emosional nya.

$$
\text { Selain dari aspek-aspek }
$$
perkembangan, kecerdasan juga harus dikembangkan pada masa emas ini. Gardner membagi kecerdasan menjadi 8 aspek kecerdasan yaitu kecerdasan linguistik, kecerdasan logika matematika, kecerdasan kinestetik, kecerdasan spasial, kecerdasan musikal, kecerdasan intrapersonal, kecerdasan interpersonal dan kecerdasan naturalis (Behjat, 2012). Kedelapan kecerdasan ini dimiliki oleh individu, hanya saja diantara delapan kecerdasan itu ada yang menonjol, ada yang seimbang dan ada juga yang kurang terlihat. Semua kecerdasan harus dikembangkan dengan baik karena kecerdasan penting untuk kehidupan anak. Salah satu kecerdasan yang penting untuk dikembangkan adalah kecerdasan interpersonal.

Kecerdasan interpersonal merupakan kemampuan seseorang dalam memahami perasaan orang lain, memotivasi dan mudah memiliki hubungan sosial yang baik dengan lingkungan sekitar. Pengembangan kecerdasan interpersonal seringkali diabaikan dan tidak terlalu diperhitungkan oleh orangtua dan guru. Para orangtua hanya sibuk mengajarkan anak-anak mereka belajar membaca, menulis dan berhitung. Menurut mereka anak cerdas itu ketika seorang anak pintar membaca, menulis dan berhitung. Namun, ada beberapa orangtua yang mengkhawatirkan kecerdasan interpersonal anaknya. Seperti penelitian yang dilakukan oleh McIntryre Transition to Kindergarten: Family Experiences and Involvement mengenai keterlibatan orangtua dan kesiapan anak memasuki Taman Kanak-kanak. Keluarga yang memiliki anak dengan dan tanpa kebutuhan khusus memiliki tingkat kekhawatiran yang sama mengenai anak mereka yang menghadiri sekolah baru, bergaul dengan teman sebaya, berpisah dari keluarga, dan bergaul bersama dengan guru taman kanak-kanak (Mcintyre, Eckert, Fiese, Digennaro, \& Wildenger, 2007). Berdasarkan hasil penelitian tersebut, menggambarkan kekhawatiran orangtua terhadap kecerdasan interpersonal anak dan sangat berharap sekolah dapat memberikan stimulasi pengembangannya.

Kecerdasan interpersonal sangat dibutuhkan oleh anak usia dini karena ketika anak memiliki kecerdasan interpersonal yang baik, anak akan mudah beradaptasi dengan lingkungan baru. Hal ini sejalan dengan penelitian yang dilakukan oleh Robinson dan Diamond tentang A Quantitative Study Of Head Start Children's Strengths, Families Perspectives, And Teachers Ratings In The Transition To Kindergarten mengungkapkan bahwa anak yang memiliki kemampuan interpersonal yang baik akan mudah menyesuaikan diri disekolah, mudah memiliki hubungan social dengan teman dan mampu mengikuti kegiatan akademik (Robinson \& Diamond, 2014). 
Namun kenyataannya, masih banyak anak yang memiliki kecerdasan interpersonal rendah. Dalam penelitiannya, Robinson dan Diamond menjelaskan dalam penelitiannya, lebih dari sepertiga guru melaporkan bahwa setidaknya setengah dari anak-anak di kelas mereka mengalami masalah pada beberapa bulan pertama di taman kanak-kanak. Petunjuk berikut adalah kesulitan yang paling sering dilaporkan siswa. $46 \%$ guru melaporkan bahwa lebih dari setengah anak-anak di kelas mengalami kesulitan mengikuti petunjuk, 34\% melaporkan bahwa lebih dari setengah mengalami kesulitan untuk bekerja secara independen, dan 30\% melaporkan bahwa lebih dari setengah mengalami kesulitan untuk bekerja sebagai bagian dari kelompok . Inilah jenis kesulitan yang membuat kelas menantang guru dan terkait dengan masalah belajar anak. Hal ini menjadi bukti dari masalah ketika anak memasuki usia sekolah, anak sulit beradaptasi, sulit berinteraksi dan sulit bergabung dalam sebuah kelompok.

Berdasarkan beberapa hasil penelitian di atas dapat dketahui bahwa penelitian terdahulu membuktikan tentang penggunaan kegiatan menggambar pada anak usia Taman Kanak-kanak. Menggambar adalah kegiatan yang sangat disenangi oleh anak-anak karena dengan menggambar anak bisa lebih mengeksplor diri nya, mengungkapkan perasaannya, mengerti orang lain sehingga kecerdasan interpersonalnya dapat dikembangkan dengan optimal. Selain itu dinyatakan bahwa kecerdasan interpersonal sangat penting untuk dikembangkan dalam pendidikan anak usia dini, dimana kecerdasan interpersonal menjadi pendukung dalam perjalanan hidup anak. Penelitian ini berbeda dengan penelitian sebelumnya, dimana peneliti menggunakan kegiatan menggambar secara bersama dalam peningkatan kecerdasan interpersonal anak.

Berdasarkan observasi awal peneliti di Taman Kanak-kanak Islam Nusantara kelompok B yang berusia 5-6 tahun dengan jumlah anak 14 orang. 6 orang anak perempuan dan 8 orang anak laki-laki. Di TK Islam Nusantara ini terdapat 10 orang anak yang belum mampu berbagi dengan temannya, belum bisa antri menunggu giliran dan belum mampu bekerjasama dengan kelompok. Selain itu, proses pembelajaran lebih diutamakan pembelajaran calistung.

Melihat kenyataan dilapangan dan dari hasil peneliti relevan tersebut, penulis merasa perlu mengadakan penelitian dengan judul "Peningkat kecerdasan interpersonal melalui kegiatan menggambar kelompok B Taman Kanak-kanak Islam Nusantara". Penulis berharap kecerdasan interpersonal anak dapat meningkat melalui kegiatan menggambar sehingga berdampak positif terhadap aspek-aspek perkembangan lainnya.

Kecerdasan jamak saling berkaitan, seperti antara kecerdasan intrapersonal dan interpersonal. Jamaris berpendapat bahwa kecerdasan intrapersonal merupakan salah satu bagian dari multiple intelligences yang berkaitan dengan kepekaan dalam melakukan introspeksi terhadap diri sendiri dan membandingkannya dengan kelemahan dan kekuatan orang lain. Sedangkan kecerdasan interpersonal berkaitan dengan kepekaan dalam membedakan dan merespon perilaku yang ditampilkan orang lain. Kecerdasan ini dapat dilihat dari kemampuan menggerakkan dan berkomunikasi dengan orang lain, bekerjasama dalam tim, serta disenangi oleh orang lain disekitarnya. Kecerdasan ini juga menyangkut kemampuan membedakan maksud tertentu, motivasi dan perasaan orang lain (Jamaris, 2017) 
$464 \mid$ Peningkatan Kecerdasan Interpersonal melalui Kegiatan Menggambar

Kecerdasan intrapersonal dan interpersonal merupakan dua kecerdasan yang saling berkaitan, karena ketika seorang anak dapat memahami dirinya, maka memahami orang lain juga dapat dilakukan dengan mudah. Pada penelitian ini, peneliti memfokuskan pada kecerdasan interpersonal.

Memiliki kecerdasan interpersonal adalah hal yang akan membuat seseorang dapat merasakan apa yang dirasakan orang lain, menangkap maksud dan motivasi orang lain, serta mampu memberikan tanggapan yang tepat sehingga orang lain bisa merasa nyaman. Sejalan dengan itu, Habeeb dan Moin mendefinisikan kecerdasan interpersonal adalah memahami orang lain. Setiap orang yang berhubungan dengan orang lain sangat membutuhkan keterampilan interpersonal, dimana kecerdasan interpersonal meliputi keterampilan berhubungan,sikap yang kooperatif, kepemimpinan, pengaruh sosial, empati dan hubungan sosial (Habeeb \& Fatema, 2016)

Tai juga menyatakan bahwa kecerdasan interpersonal adalah kemampuan untuk mengerti dan berinteraksi secara aktif dengan orang lain. Kemampuan ini melibatkan komunikasi verbal dan non verbal, kemampuan untuk mencatat perbedaan antara lain, kepekaan terhadap suasana hati dan tempramen orang lain, dan kemampuan untuk menghibur berbagai perspektif. Guru, pekerja sosial, aktor, dan politisi adalah orang-orang yang cerdas secara interpersonal. (Tai, 2014)

Sejalan dengan itu, Azid berperndapat bahwa kecerdasan interpersonal berhubungan erat dengan emosi. Individu yang memiliki kecerdasan interpersonal akan memiliki kemampuan untuk memahami perasaan orang lain, bermotivasi tinggi, dan dapat berinteraksi dengan baik dengan orang lain melalui komunikasi yang efektif (Azid \& Yaacob, 2016).
Jadi, kecerdasan interpersonal adalah kemampuan seseorang untuk memahami perasaan orang lain (empati) dan memberi respon (simpati), mampu berinteraksi dan berkomunikasi dengan orang lain, mampu mengorganisir orang lain, serta mampu bekerjasama.

Kecerdasan interpersonal usia 5-6 tahun perlu untuk ditingkatkan mengingat seharusnya pada usia ini anak sudah mempunyai banyak teman, mampu melibatkan diri dalam kelompok, menikmati permainan keolmpok, serta dapat menjadi penasehat diantara temantemannya. Ketika anak cerdas interpersonalnya, maka anak akan mudah diterima di lingkungan sekitarnya, karena anak yang cerdas interpersonal pada umumnya akan membuat orang lain nyaman dengan dirinya.

Anak dengan kecerdasan interpersonal yang tinggi dapat memahami bagaimana perasaan teman-temannya dengan melihat ekspresi wajah temannya, memiliki dua atau lebih teman dekat, memberikan saran kepada teman-teman yang memiliki maslah, seperti nasehat orang lain, memiliki rasa yang baik dari empati atau kepedulian terhadap orang lain, mencari dukungan untuk bekerja dan bermain dengan anak-anak lain, mencari dukungan dari kelompok. (Sonawat, 2008)

Sejalan dengan itu, menurut Suyadi, ciri-ciri anak usia dini usia 5-6 tahun yang mempunyai kecerdasan interpersonal yang tinggi adalah a) mengetahui bagaimana cara menunggu giliran, b) berani berangkat ke sekolah tanpa di antar, c) tertib menggunakan alat atau benda mainan sesuai dengan fungsinya, d) tertib dan terbiasa menunggu giliran atau antre, e) memahami akibat jika melakukan pelanggaran dan berani bertanggung jawab (tidak menangis karena takut dihukum), f) mampu memimpin kelompok bermain yang lebih besar (antara 4-8 orang), g) terampil 
memecahkan masalah sederhana.(Suyadi, 2010)

Pengembangan

kecerdasan interpersonal sangat perlu untuk dikembangkan. Ada berbagai strategi yang digunakan untuk mengembangkan kecerdasan interpersonal anak, seperti yang dikemukakan oleh Sujiono, cara mengembangkan kecerdasan interpersonal pada anak yaitu mengembangkan dukungan kelompok, menetapkan aturan tingkah laku, memberi kesempatan bertanggung jawab di rumah, bersama-sama menyelesaikan konflik, melakukan kegiatan sosial di lingkungan, menghargai perbedaan pendapat antara anak dengan teman sebaya, menumbuhkan sikap ramah dan memahami keragaman budaya lingkungan sosial dan melatih kesabaran menunggu giliran berbicara, serta mendengarkan pembicaraan orang lain terlebih dahulu (Sujiono, 2009)

Strategi tersebut dapat diterapkan dalam kegiatan menggambar. Hal itu disebabkan menggambar merupakan kegiatan yang sangat disenangi oleh anakanak, karena saat menggambar mereka bermain dengan warna, bentuk dan alat-alat gambar. Sebelum anak mampu menuangkan pemikirannya melalui kata, anak telah memulainya dengan membuat gambaran didalam pikirannya. Seiring berjalan nya waktu, ketika anak tidak sepenuhnya mampu mengungkapkan pemikirannya melalui kata, anak mulai menggambar. Menurut Muis, menggambar merupakan suatu cara untuk membuat sebuah kesan atau gambar, yang merupakan suatu proses membuat tanda pada suatu permukaan dengan mencoba memberi tekanan atau memindahkan alat dari suatu permukaan (Muis, 2013)

Farokhi dan Masoud juga berpendapat Drawing is a symbolic expression of the inner psyche (the unconscious). The unconscious part of the psyche can appear through symbols (drawing). Drawing is a direct communication from the unconscious, and it cannot be camouflaged as easily as in the case of communication with words. When a drawing appears from the unconscious, a vast amount of psychological information is generated, and the depths of the drawer's psyche can be felt through the drawing (Farokhi \& Hashemi, 2011).

Menurut Farokhi dan Masoud, menggambar adalah ekspresi simbolis dan batin (the unconscious). Perasaan alam bawah sadar bisa muncul melalui simbol (gambar). Menggambar adalah komunikasi langsung dari alam bawah sadar, dan tidak dapat disamarkan semudah dalam hal komunikasi dengan kata-kata. Ketika sebuah gambar muncul dari alam bawah sadar, sejumlah besar informasi psikologis dihasilkan, dan kedalaman jiwa dan dapat dirasakan melalui gambar.

Menurut Davido, kegiatan menggambar bagi anak merupakan sebuah permainan mimpi, dan kenyataan. Gambar adalah sebuah permainan, selama itu tidak memaksa, justru dapat menghibur pembuatnya. Selain itu, gambar mengungkapkan banyak kenyataan dalam kehidupan. Gambar adalah sebuah mimpi di atas kertas, dimana muncul keinginankeinginan, baik disadari maupun tidak. Gambar adalah sebuah kenyataan dari pikiran-pikiran anak, pada moment tertentu, mendorongnya untuk menggambar (Davido, 2012)

Dari uraian di atas, dapat disimpulkan bahwa menggambar merupakan kegiatan yang menyenangkan, kegiatan yang menghibur bagi sipembuatnya, alat untuk mengungkapkan pemikiran, keinginan dan perasaan, serta gambar dapat mengungkap banyak kenyataan dalam kehidupan.

\section{METODOLOGI}

Metode yang digunakan dalam penelitian ini adalah penelitian tindakan 
466 | Peningkatan Kecerdasan Interpersonal melalui Kegiatan Menggambar

yang mengacu kepada model Kemiss dan Mc. Tagart. Adapun prosedur kerja dalam penelitian ini adalah perencanaan, tindakan dan observasi, dan refleksi. Langkah ini dilakukan berulang sampai dicapai keberhasian atau hasil yang diinginkan. Setelah tahapan dari siklus satu selesai, kemudian dilanjutkan dengan perencanaan ulang, tindakan dan observasi, dan refleksi untuk siklus berikutnya.

Kriteria keberhasilan tindakan dalam penelitian ini mengacu pada kriteria yang ditetapkan oleh Mills, yang menyatakan bahwa penelitian tindakan memiliki target persentase menjadi $71 \%$ setelah melakukan tindakan pada subjek penelitian. Artinya, penelitian ini dikatakan berhasil jika $71 \%$ dari jumlah anak di kelas sudah mencapai standar yang telah ditetapkan oleh kolaborator yaitu $75 \%$ dengan mempertimbangkan situasi dan kondisi sekolah.

\section{HASIL DAN PEMBAHASAN}

Penelitian tindakan ini terfokus pada peningkatan kecerdasan interpersonal anak kelompok B usia 5-6 tahun dengan aspek memahami perasaan orang lain, berinteraksi dan berkomunikasi, mengorganisir dan bekerjasama. Aspek memahami perasaan orang lain memiliki dua indikator, aspek berinteraksi dan berkomunikasi memiliki dua indikator, aspek mengorganisir memiliki dua indikator dan aspek bekerjasama memiliki dua indikator.

Hasil tindakan kegiatan menggambar dalam meningkatkan kecerdasan interpersonal, antara lain adalah :

Kesepakatan antara peneliti dan kolaborator dimana persentase rata-rata kriteria keberhasilan yang ditetapkan sebesar $75 \%$, maka penelitian yang dilakukan di kelompok B TK Islam Nusantara dinyatakan berhasil karena anak telah mengalami peningkatan perolehan skor minimal $75 \%$. Peningkatan keberhasilan penelitian di awal pra-tindakan dilakukan untuk menentuan persentase kecerdasan interpersonal anak sebesar $50.89 \%$, meningkat menjadi $64.55 \%$ setelah siklus pertama, dan meningkat menjadi $85 \%$ setelah siklus kedua.

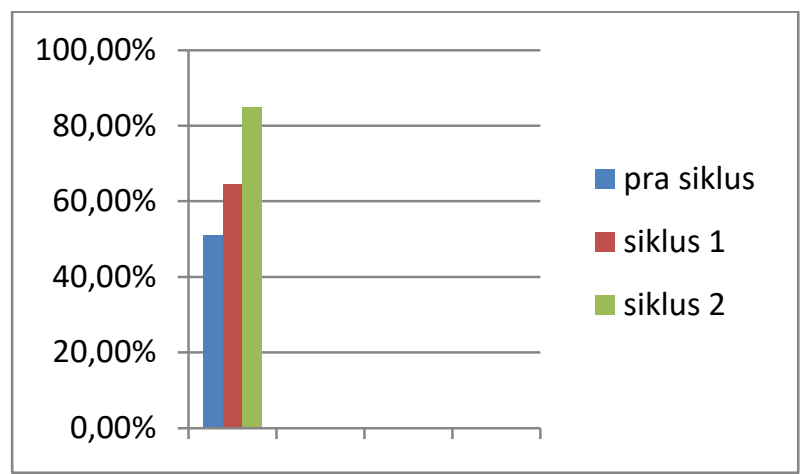

\section{Grafik peningkatan kecerdasan interpersonal anak TK Islam Nusantara}

Indikator interaksi mengalami peningkatan dari pra siklus ke siklus I hingga siklus II. Pada akhir siklus I, kemampuan interaksi anak meningkat dari kategori mulai berkembang (MB) dengan skor rata-rata kelas 4.1 menjadi berkembang sesuai harapan (BSH) dengan skor rata-rata kelas 5.1. pada akhir siklus II, kemampuan interaksi anak mencapai skor rata-rata kelas 6.6 dan masuk pada kategori berkembang sangat baik (BSB). Hal ini ditunjukkan dengan anak sudah mampu menceritakan gambar yang telah dibuat. Selain itu, saat menggambar anak sudah mampu mengkomunikasikan gambar yang dibuat.

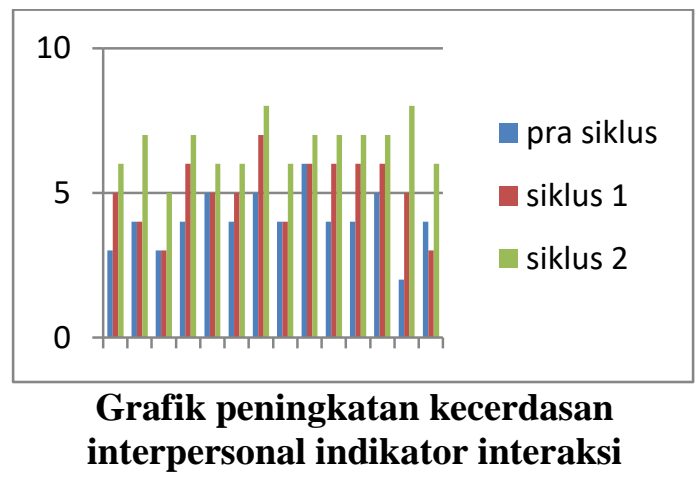


Peningkatan juga terjadi pada Indikator mengambil peran dalam kelompok mengalami peningkatan dari pra siklus ke siklus I hingga siklus II. Pada akhir siklus I, kemampuan mengambil peran dalam kelompok anak meningkat dari kategori mulai berkembang (MB) dengan skor rata-rata kelas 4.4 menjadi berkembang sesuai harapan $(\mathrm{BSH})$ dengan skor rata-rata kelas 5.5. pada akhir siklus II, kemampuan mengambil peran dalam kelompok anak mencapai skor rata-rata kelas 6.2 dan masuk pada kategori berkembang sangat baik (BSB). Hal ini dibuktikan saat abi sudah mampu membagi tugas kepada temannya gambar apa yang akan dibuat dan dimana. Selain itu juga dibuktikan oleh deden yang sudah mampu memimpin barisan sebelum masuk kelas.

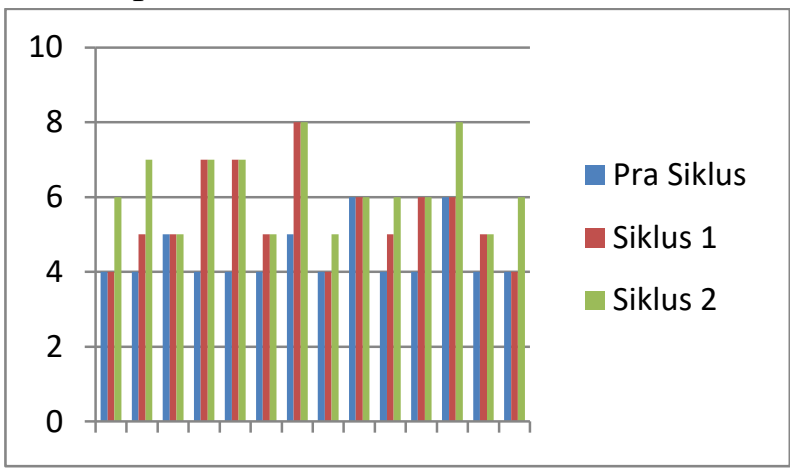

Grafik peningkatan kecerdasan interpersonal indikator mengambil peran dalam kelompok

Indikator terlibat dalam kegiatan kelompok juga mengalami peningkatan dari pra siklus ke siklus I hingga siklus II. Pada akhir siklus I, kemampuan terlibat dalam kegiatan kelompok meningkat dari kategori mulai berkembang (MB) dengan skor ratarata kelas 4.1 menjadi berkembang sesuai harapan $(\mathrm{BSH})$ dengan skor rata-rata kelas 5.4. pada akhir siklus II, kemampuan terlibat dalam kegiatan kelompok mencapai skor rata-rata kelas 7 dan masuk pada kategori berkembang sangat baik (BSB) dan mencapai target yang telah ditentukan oleh peneliti dengan kolaborator.

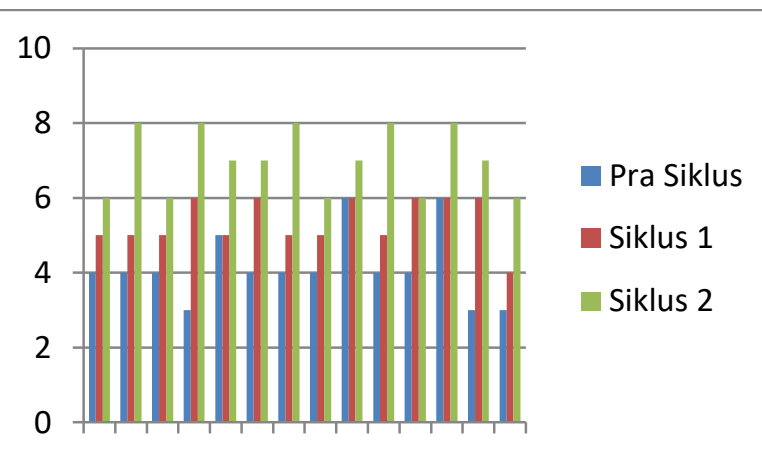

Grafik peningkatan kecerdasan interpersonal indikator terlibat dalam kegiatan kelompok

Kecerdasan interpersonal dapat ditingkatkan melalui kegiatan seni, salah satunya yaitu dengan kegiatan menggambar. Melalui kegiatan menggambar, anak dapat berbagi dengan temannya, menghargai coretan yang dibuat oleh temannya serta anak akan mencoba untuk berbagi ruang dan ide pikirannya.

Hal itu sejalan dengan pernyataan Papandreou, The interactions carried out among children drawing collaboratively show that they can help them co-construct symbols and meanings. Young children, to construct and trans-form symbols and meanings and solve various semiotic problems, make genuine thinking efforts (Papandreou, 2014). Interaksi yang dilakukan di antara anak-anak yang menggambar secara kolaboratif menunjukkan bahwa mereka dapat membantu mereka membangun simbol dan makna bersama. Anak kecil, untuk membangun dan mentransformasikan simbol dan makna dan memecahkan berbagai masalah semiotik, melakukan upaya berpikir yang sejati.

Pendapat ini juga didukung oleh pendapat Crosser yang menyatakan bahwa: Children can engage in social interaction as they draw with or show their creations to others. As young children sit together, each drawing, they talk, share stories, and trade materials. This is a basis for prosocial interaction that is practiced in an authentic 
situation. Similarly, the child who saves his or her scribble picture to show daddy is demonstrating his or her use of drawing for social interaction as well as emotional support.

Anak-anak dapat terlibat dalam interaksi sosial saat mereka menggambar atau menunjukkan ciptaan mereka kepada orang lain. Saat anak kecil duduk bersama, masing-masing menggambar, mereka berbicara, berbagi cerita. Hal Ini adalah dasar interaksi prososial yang dipraktikkan dalam situasi otentik. Demikian pula, anak yang menyimpan gambar tulisan tangannya untuk menunjukkan pada ayahnya menunjukkan penggunaan gambar untuk interaksi sosial dan juga dukungan emosionalnya. (Crosser, 2008)

Maspinal dalam (Iswantiningtyas \& Wulansari, 2019) menyebutkan pendidikan karakter bagi anak usia dini dapat dilakukan terutama oleh orang tua dan guru melalui pembiasaan atau percontohan dalam berbagai kegiatan pembelajaran bercerita, menggambar, bermain dengan alat permainan tradisional, menyulam, bernyanyi.

Sejalan dengan itu, mengenai interaksi sosial anak juga dikemukakan oleh Hopperstad yaitu interaction adds support to the process of forming visual mean-ing, a quality which in turn may make the children more confident about their drawing, motivate the children to draw more and also represent a learning potential. The informative interaction I have observed is particularly interesting here. This interaction concerns the signs' capability of communicating and shows the children's interest in being understood and in understanding the meaning of other children's drawings (Hopperstad, 2008). interaksi antar rekan memberi dukungan pada proses pembentukan makna visual, kualitas yang pada gilirannya dapat membuat anak lebih percaya diri, memotivasi anak untuk menggambar lebih banyak dan juga mewakili potensi belajar. Interaksi informatif yang saya amati sangat menarik di sini. Interaksi ini menyangkut kemampuan untuk berkomunikasi dan menunjukkan minat anak untuk dipahami dan memahami makna gambar anak-anak lainnya.

\section{KESIMPULAN}

Berdasarkan hasil penelitian yang telah dilakukan, didapat hasil dengan analisis data pra siklus dengan perolehan persentase TCP sebesar $50.89 \%$ pada siklus I sebesar $64.55 \%$ dan pada siklus II menjadi $85 \%$. sebagaimana yang telah disepakatii dengan kolaborator bahwa penelitian ini dkatan berhasil apabila 10 dari 14 yang telah berhasil menurut Mills $71 \%$. Berada pada kategori berkembang sesuai harapan dan pada penelitiian ini 10 anak sudah mencapai pada kategori berkembang sesuai harapan. Hasil yang diperoleh menunnjkan TCP kecerdasan interpersonal anak telah mencapai kriteria yang diharapkan.

Berdasarkan data kualitatif, terlihat adanya peningkatan kecerdasan interpersonal anak usia 5-6 tahun melalui pemberian tindakan berupa kegiatan menggambar. Peningkatan kecerdasan interpersonal anak terlihat ketika anak berkomunikasi dengan teman sebayanya atau orang yang lebih tua, anak bekerja sama dengan teman sebayanya atau orang yang lebih tua, anak tidak memilih teman, mau bergantian saat mengerjakan tugas maupun dalam kegiatan mencuci tangan sebelum makan, percaya diri memimpin barisan serta anak mampu menghargai hasil karya teman.

Dengan demikian pemberian tindakan berupa "kegiatan menggambar dapat meningkatkan kecerdasan interpersonal anak pada kelompok B TK Islam Nusantara." 


\section{UCAPAN TERIMA KASIH}

Terimakasih Kepada kedua orangtua yang telah memberikan dukungan kepada peneliti. Terimakasih juga peneliti ucapkan kepada murid, kepala sekolah dan guru TK Islam Nusantara. Terimakasi juga kepada Pembimbing 1 dan pembimbing 2 yang telah membimbing peneliti dalam pembuatan jurnal penelitian ini.

\section{DAFTAR PUSTAKA}

Azid, N. H., \& Yaacob, A. (2016). Enriching Orphans' Potentials through Interpersonal and Intrapersonal Intelligence Enrichment Activities. International Journal of Instruction, 9(1), 17-32. https://doi.org/10.12973/iji.2016.913a

Behjat, F. (2012). Interpersonal and intrapersonal intelligences: Do they really work in foreign-language learning? Procedia - Social and Behavioral Sciences, 32(2010), 351355.

https://doi.org/10.1016/j.sbspro.2012.0 1.052

Crosser, S. (n.d.). artikel hubungan menggambar dengan interaksi sosial. Exlcelligence learning corporation.

Davido, R. (2012). Mengenal Anak Melalui Gambar. jakarta: salemba humanika.

Farokhi, M., \& Hashemi, M. (2011). Social and The Ana lysis of Children' $s$ Drawings: Social , Emotional, Physical, and Psychological aspects. OO, 2219-2224. https://doi.org/10.1016/j.sbspro.2011.1 0.433

Habeeb, K. T., \& Fatema, M. (2016). Effect of intrapersonal and interpersonal awareness dimensions of emotional intelligence on stress management of adolescents. 2(10), 589-592.

Hopperstad, M. H. (2008). Relationships between children' $s$ drawing and accompanying peer interaction in teacher-initiated drawing sessions. $16(2)$, 133-150. https://doi.org/10.1080/096697608020
44844

Iswantiningtyas, V., \& Wulansari, W. (2019). Penanaman Pendidikan Karakter pada Model Pembelajaran BCCT (Beyond Centers and Circle Time). Jurnal Obsesi : Jurnal Pendidikan Anak Usia Dini, 3(1), 110. https://doi.org/10.31004/obsesi.v3i1.1 06

Jamaris, M. (2017). Pengukuran Kecerdasan Jamak. Bogor: Ghalia Indonesia.

Mcintyre, L. L., Eckert, T. L., Fiese, B. H., Digennaro, F. D., \& Wildenger, L. K. (2007). Transition to Kindergarten: Family Experiences and Involvement. 35(1). https://doi.org/10.1007/s10643007-0175-6

Muis, A. (2013). Bunga Rampai Pendidikan Anak Usia Dini. jakarta: FIP Press.

Papandreou, M. (2014). Journal of Research in Childhood Communicating and Thinking Through Drawing Activity in Early Childhood. (December), 37-41. https://doi.org/10.1080/02568543.2013 .851131

Robinson, C. D., \& Diamond, K. E. (2014). A Quantitative Study of Head Start Children' $s$ Strengths, Families ' Perspectives, and Teachers 'Ratings in the Transition to Kindergarten. 7784. https://doi.org/10.1007/s10643013-0587-4

Sonawat, R. and P. G. (2008). Multiple Intelligences for Preschool Children. mumbai: multi-tech publishing co.

Sujiono, Y. N. (2009). Konsep Dasar Pendidikan Anak Usia Dini. jakarta: PT. Indeks.

Suyadi. (2010). Psikologi Belajar PAUD. Yogyakarta: Pedagogi.

Tai, F. (2014). Exploring Multiple Intelligences. 10(11), 11-21. 